\title{
JAMAIS FOMOS PRÉ-MODERNOS: AS TRANSFORMAÇÕES NAS RELIGIOSIDADES BRASILEIRAS
}

WE WERE NEVER PRE-MODERN:

THE TRANSFORMATIONS IN THE

BRAZILIAN RELIGIOSITY

\begin{abstract}
Amurabi Oliveira*
RESUMO: O campo religioso brasileiro tem-se marcado por intensas transformações nas últimas décadas, não à toa, para muitos pesquisadores a Sociologia da Religião no Brasil, ao menos desde 1960, tem sido uma Sociologia da mudança religiosa. Visando contribuir para esse debate, abarcando também a Antropologia da Religião, este trabalho visa realizar uma análise das transformações sofridas nas religiosidades brasileiras, partindo tanto de uma revisão da literatura, considerando como diversos pesquisadores das Ciências Sociais têm compreendido os diversos credos no Brasil, como do substrato teórico fornecido Bourdieu para compreendermos a dinâmica e as idiossincrasias do campo religioso brasileiro.
\end{abstract}

Palavras Chaves: campo religioso; sociologia da religião; antropologia da religião; mudança religiosa.

\footnotetext{
* Doutor em Sociologia e Professor do Programa de Pós-Graduação em Educação da Universidade Federal de Alagoas - UFAL, Maceió, AL; e-mail: amurabi_cs@hotmail.com 65| Século XXI, Revista de Ciências Sociais, v.3, nº 2, p.65-111, jul./dez. 2013 ISSN: 2236-6725
} 
ABSTRACT: Brazilian religious field has been marked by intense transformations in recent decades, not for nothing, for many researchers Sociology of Religion in Brazil, at least since 1960, has been a sociology of religious change. To contribute to this debate, covering also the anthropology of religion, this work aims to conduct an analysis of the transformations in the Brazilian religiosity, from both a literature review, considering how many researchers in the social sciences have understood the various faiths in Brazil, as the theoretical basis provided by Bourdieu for understanding the dynamics and idiosyncrasies of the Brazilian religious field.

Keywords: religious field, the sociology of religion, anthropology of religion, religious change.

\section{O SAGRADO, O PROFANO E O SIMBÓLICO: O HOMEM E SEUS DEUSES}

Como nos coloca Bastide (2006) nós fabricamos deuses, e essa tem sido uma das características mais instigantes do homem, sua produção simbólica capaz de dividir o universo em dois polos, o sagrado e o profano (Durkheim, 2003; Eliade, 2008), que por mais que situados de forma apartada, ou mesmo em oposição, se tocam, se entrelaçam lascivamente, constituindo o universo de referência a partir do qual o homem se situa no mundo. Considerando a universalidade da capacidade humana de simbolizar (Durand, 2001), o sagrado também acompanha o homem nas mais diversas culturas, no tempo e no espaço, tornando-se uma das peculiaridades que mais instigam a imaginação das ciências sociais, justamente, por se apresentar como uma característica humana aparentemente universal, mas também singular, tanto no nível das culturas, quando no nível da experiência e da subjetividade.

A criação de cosmologias, e cosmogonias, se dá não apenas no nível da abstração, mas também no nível das práticas sociais, pois o processo religioso, ainda que voltado para o sagrado, possui implicações sobre o profano, já que, as práticas religiosas também se 
reverberam em formas de agir no mundo (Weber, 1983, 1999, 2004).

Desse modo, os esquemas de categorização e classificação emergem e, dinamizam-se, a partir do substrato social, o que implica em dizer que, sua compreensão se dá a partir da realidade social e cultural, em que os sujeitos estão envolvidos (Dukheim, Ibidem). Da mesma forma, a criação de mitologias, transparece processos sociais e históricos, que podem remeter tanto a um passado que legitima, ou explica uma realidade atual, como, a um conjunto de aspirações futuras, que podem, também, possui um caráter explicativo sobre o presente.

O sagrado repactua o tempo, dando-lhe um novo sentido, bem como, reconfigura o espaço, reordenando-o. O rito permite ao homem simbolizar uma repactuação com tempo, com o espaço, com os deuses, e consigo mesmo, perfazendo as palavras, os gestos - e tudo mais que ele entender como sagrado - que teria ocorrido no tempo antes do tempo, o rito permite ao homem imergir no in illo tempore (Eliade, 2001). O rito também nos permite ordenar o mundo profano, primeiramente, pela própria separação com relação ao sagrado, segundo Douglas (1991):

Para nós os objetos e os lugares sagrados devem ser protegidos das impurezas. O sagrado e o impuro são pólos postos. Não podemos confundi-los, como não poderíamos confundir a fome com a saciedade, o sono com a vigília e, contudo, parece que é característico das religiões primitivas não distinguir claramente o sagrado do impuro. (Ibidem, p. 20).

Tal separação se dá tanto no nível do espaço, quanto do tempo, ao menos em princípio, pois, como já anunciamos, tais polos imbricam-se, em especial no âmbito festivo que a religião toma, por vezes, onde a experiência da própria dança se funde à experiência do divino.

Quando nos debruçamos, sobre a idiossincrasia da realidade social brasileira, esta interpenetração entre o sagrado e o profano, fica ainda mais evidente, Freyre (2006), nos demonstra como, já em Portugal, a festa de Corpus Christi, por exemplo, tomava ares deveras bacantes, onde, se poderia ter a impressão, que os santos mostra- 
vam-se desejosos por descer dos altares e, acompanhar a proscrição, onde elementos diversos, fundiam-se, tomando, posteriormente, ares luso-tropicais. Nas palavras do autor:

Primeiro a procissão organizando-se ainda dentro da igreja: pendões, bandeiras, dançarinos, apóstolos, imperadores, diabos, santos, rabis comprimindo-se, pondo-se em ordem. Pranchadas de soldados para dar modos aos salientes. À frente, um grupo dançando 'judinga', dança judia. O rabi levando a toura. Depois dessa seriedade toda, um palhaço, fazendo mungangas. Uma serpente enorme, de pano pintado, sobre uma armação de pau, e vários homens de baixo. Ferreiros. Carpinteiros. Uma dança de ciganos. Outra de mouros. São Pedro. Pedreiros trazendo nas mãos castelos pequenos, como de brinquedo. Regateiras e peixeiras dançando e cantando. Barqueiros com a imagem de São Cristovão. Pastores. Macacos. São João rodeado de sapateiros. A Tentação representada por mulher dançando, aos requebros. São Jorge, protetor do exército, a cavalo e aclamado em oposição a Santo Iago, protetor dos espanhóis. Abraão. Judite. Davi. Baco sentado sobre uma pipa. Uma Vênus seminua. Nossa Senhora em um jumentinho. O Menino-Deus. São Jorge. São Sebastião nu cercado de homens malvados fingindo que vão atirar nele. Frades. Freiras. Cruzes alçadas. Hinos sacros. O rei. Fidalgos. Toda a vida portuguesa, enfim. Depois das conquistas, acrescentaram-se danças de índios e negros às figuras da procissão do reino. (Ibidem, p. 356-357)

Ante a pluralidade religiosa, que instaura no Brasil, este aspecto torna-se mais evidente, como no caso das religiões afro-brasileiras, Motta (1995), nos demonstra a centralidade que a festa, o sacrifício e o transe possuem, em tais práticas religiosas no Brasil:

Dança, entusiasmo, transe, sacrifício, essas noções se implicam, estão penetradas pela mesma lógica, o transe sendo a continuação do sacrifício por outros meios7. Pois os deuses, para que simplesmente existam, precisam em primeiro lugar de ser nutridos com o sangue 
dos animais. Mas precisam também dos corpos dos seus fiéis, nos quais vão manifestar-se pelo transe de êxtase. Pois o que não se manifesta, não existe. (Ibidem, p. 38)

Em meio a esta profusão de festividades, e de lascividade, entre polos em princípio apartados, voltamos ao nosso ponto inicial, da religião como expressão de uma dada realidade social. E como tal, transforma-se no tempo, considerando-se o caráter histórico da realidade humana. Sendo assim, interessa-nos neste trabalho discorrer sobre os processos de transformação nas religiosidades brasileiras, atrelando-as às mudanças mais amplas, da sociedade brasileira, mas também reconhecendo sua dinâmica singular, enquanto campo simbólico, para tanto, nos utilizaremos principalmente do substrato teórico de Bourdieu, bem como recorreremos a uma ampla gama de autores que têm pensado diversas esferas do universo religioso brasileiro, sem que com isso resumamos este trabalho a uma revisão bibliográfica em torno da abordagem das Ciências Sociais sobre a religião, tarefa já empreendida por autores como Montero (1999); Almeida (2010); Pierucci e Mariano (2010).

\section{DEUS E O DIABO NA TERRA DO SOL: RELIGIÃO E MA- TRIZ RELIGIOSA NO BRASIL}

No final do século XIV, início dos XV, o mundo eurocêntrico passava por diversas transformações, percebendo que seus horizontes eram mais largos, do que poderiam imaginar, e, para além de um universo idílico a povoar, encontraram um mundo já povoado, por outros povos e outras realidades simbólicas. A chegada às Américas causou estranhamento e fascínio, os horizontes e olhares estavam cruzados, causando visões opostas de um paraíso na Terra (Holanda, 2010). Ainda que Freyre (2006) aponte para uma plasticidade do Português, que permitiria uma maior adaptação cultural em relação aos trópicos, criando aqui um "Novo Mundo" (Freyre, 2011), é inegável que, a configuração destes encontros, se deu em meio a relações de poder postas, que buscaram naturalizar o lugar que estes sujeitos ocupam na 
hierarquia social, tal como é posto no projeto colonial (Memi, 2007).

O Novo Mundo mostrava-se ambíguo, por um lado, seus habitantes (que poderiam ser ou não humanos num olhar eurocêntrico) pareciam representar a própria visão do paraíso (Holanda, 2010), por outro, suas práticas "selvagens" eram heteróclitas, poligâmicos, politeístas e panteístas, canibais. Seu exotismo demandava um cuidar, que implicava em um controlar. Neste momento histórico, o Estado e a Igreja realizam uma divisão tácita do trabalho colonial, cabendo a esta o domínio das almas, e àquele o domínio dos corpos, ainda que tal divisão, por vezes, tenha enfrentado embates por assumirem posturas destoantes, em alguns momentos (Ribeiro, 2006). Tal divisão. implicou numa colonização demarcada por uma bifrontalidade, angariando novas terras para o poder temporal dos monarcas europeus, e novas almas para o papado (Neves, 1978).

Havia a persistência de um motivo edênico, no processo colonial - Colombo, por deveras vezes, buscou demonstrar que chegara às imediações do paraíso - que se ligava a uma missão redentora, que os povos ibéricos acreditavam portar, cuja implicação mais emblemática, para os povos "autóctones", seria um intenso, e violento, processo de aculturação. No entanto, devemos destacar, que não defendemos aqui uma relação de passividade, dos ameríndios com relação aos europeus, muito pelo contrário, as disputas se deram tanto em um nível belicoso, quanto simbólico.

Notoriamente, as questões que se travaram no campo religioso brasileiro, se deram orbitando em torno do catolicismo, que se mostrou (e se mostra) como o grande centro gravitacional da religiosidade brasileira, uma vez que, o mesmo ocupava uma posição singular, nas relações de poder e de dominação, que se instauraram no processo colonial. Ainda que possamos defender que, o ethos religioso brasileiro, encontra-se no sincretismo e não no catolicismo (Andrade, 2002), devemos enfatizar que, as construções sincréticas que se desenvolveram, na realidade social brasileira, se deram num intenso diálogo com o catolicismo, seja aproximando-se, ou distanciando-se, com relação ao mesmo.

$\mathrm{O}$ arranjo da matriz religiosa brasileira, ao menos neste mo- 
mento histórico, remeteu a uma articulação entre os elementos do catolicismo, das práticas religiosas indígenas, das africanas, com a posterior vinda dos africanos escravizados, dentre outras tradições religiosas, que estavam dissolvidas no âmago do processo colonial, como a herança moura ${ }^{1}$, e mesmo as tradições dos cristãos novos ${ }^{2}$.

Estes encontros implicaram em rearranjos simbólicos, e disposicionais, com relação a uma nova realidade social, e cultural, que se apresentava. Nenhum destes elementos reproduziram-se completamente, mudanças, adaptações e novos formas foram assumidas. Os contatos, encontros e experiências não passaram despercebidos, de modo que, uma nova realidade religiosa emergia, neste cenário, trazendo uma formatação idiossincrática, tanto com relação ao cenário religioso europeu, quanto com relação ao cenário ameríndio e africano.

\section{SINCRETISMO E IDENTIDADE RELIGIOSA NO BRASIL}

Como já apontamos, as práticas religiosas no Brasil passaram a se configurar, a partir de uma teia de relações de poder, que se instauraram desde o período colonial, em que, a relação instaurada, entre o Estado Nacional e a Igreja Católica, levou a uma configuração religiosa, na qual, o diálogo com o catolicismo mostrou-se imprescindível para qualquer crença, ao menos, para aqueles que angariavam a legitimação, dentro da ordem social vigente.

Tal dinâmica, levou os sujeitos a desenvolverem estratégias, com relação a articulação de seus universos simbólicos, bem como com relação às suas identidades. Ao traçar uma compreensão da realidade social, a partir da ideia de campo, tal como proposta por Bourdieu (2004b, 2005, 2007, 2009) - cuja categoria, o autor elaborou visando superar um "erro de curto-circuito". Tal equívoco, consiste em tentar atrelar, de forma automática, determinadas práticas sociais

\footnotetext{
${ }^{1}$ Este termo refere-se, de modo geral, às populações islamizadas do Noroeste da África, responsáveis pela invasão islâmica da Península Ibérica, a partir do século VIII. A "reconsquista" completa da Península Ibérica, só se deu no final do século XV, em todo o caso, tal presença deixou traços profundos na cultura dos países Ibéricos.

${ }^{2}$ Era a designação dada em Portugal, Espanha e Brasil, aos judeus e muçulmanos recém-convertidos ao cristianismo, este termo, em todo o caso, tem um emprego mais recorrente no caso dos judeus.

71| Século XXI, Revista de Ciências Sociais, v.3, nº 2, p.65-111, jul./dez. 2013 ISSN: 2236-6725
} 
a questões macrossociais (revoluções, guerras, etc), ou de dar uma completa autonomia às mesmas - assumimos uma perspectiva em que a dinâmica do campo religioso passa a ser assumida considerando uma realidade própria, ainda que atrelada a outras esferas, tal realidade implica em ações e escolhas dos atores sociais, em que, estratégias são assumidas, visando determinados fins.

É válido destacar ainda que, para Bourdieu (2004b), os campos são marcados por serem relativamente autônomos, portanto, possuem regras próprias, ao mesmo tempo em que, sofrem influências externas, oriundas de outros campos, tanto, que "Uma das manifestações mais visíveis da autonomia do campo é sua capacidade de refratar, retraduzindo sob uma forma específica as pressões ou as demandas externas." (Ibidem, p. 22)

Cada campo será formado por um determinado tipo de capital simbólico, de modo que, sua estrutura será dada a partir da distribuição deste capital, entre seus agentes. Aqueles que possuem maior quantia de capital simbólico serão capazes de "deformar" o campo de acordo com os seus interesses. Possuindo maior peso na elaboração das "regras do jogo", que determinam, dentre outras coisas, a forma de se acessar determinado tipo de capital. Na definição do autor, o capital simbólico é:

[...] o conjunto de recursos atuais ou potenciais que estão ligados à posse de uma rede durável de relações mais ou menos institucionalizadas de interconhecimento e de inter-reconhecimento ou, em outros termos, à vinculação a um grupo, como conjunto de agentes que não somente são dotados de propriedades comuns (passíveis de serem percebidas pelo observador, pelos outros ou por eles mesmos), mas também são unidos por ligações permanentes e úteis. Essas ligações são irredutíveis às relações objetivadas de proximidade no espaço físico (geográfico) ou no espaço econômico e social porque são fundadas em trocas inseparavelmente materiais e simbólicas cuja instauração e perpetuação supõem o re-conhecimento dessa proximidade. (Bourdieu, 1998, p. 67) 
Existem diversos campos simbólicos, como o campo religioso, literário, econômico, dentre outros, todos relativamente autônomos, havendo no campo econômico uma "autonomia relativa" sensivelmente superior, com relação aos demais campos (Bourdieu, 2005). Tendencialmente, os agentes do campo, que possuem maior quantia de capital simbólico - que pode se apresentar de forma incorporada, objetivada ou institucionalizada ${ }^{3}$ - apresentarão posturas ortodoxas, visando, com isso, sua manutenção posicional. Tal feito será realizado, através da chamada violência simbólica, que, para Bourdieu (2005), é a dominação de uma classe sobre a outra, o que é garantido pelos sistemas simbólicos que, enquanto instrumentos estruturados e estruturantes de comunicação e de conhecimento, cumprem sua função política de instrumentos de imposição ou de legitimação da dominação. Ao mesmo tempo, aqueles que possuem menor quantia de capital simbólico, apresentarão posturas heterodoxas, lançando mão de estratégias, para angariar maior quantia de capital simbólico. No plano religioso, este movimento se apresenta de forma "clara" através do sincretismo, compreendido aqui como:

[...] um processo fundamental, tendencialmente universal ainda que diferenciado em seus graus, níveis e modalidades: O processo de usar relações apreendidas no mundo do outro para entender, modificar e/ou eventualmente transfi gurar seu próprio universo simbólico, ou ainda o modo pelo qual as sociedades humanas, quando confrontadas - igual ou desigualmente - a outra sociedade, outro grupo social, ou simplesmente outra visão do mundo, redefi nem sua própria identidade a partir da alteridade cultural. (Sanchis, 1994, p. 10).

\footnotetext{
${ }^{3}$ Segundo Bourdieu (1998) o capital simbólico apresenta-se sob três formas: a) no estado incorporado, sob a forma de disposições duráveis no organismo. Sua acumulação liga-se ao próprio corpo, o que demanda tempo, pressupondo, desse modo, um processo de inculcação e assimilação; b) no estado objetivado, se apresentando sob a forma de bens culturais (livros, instrumentos, máquinas, vestuário, etc), que podem ser transmitidos de forma relativamente instantânea, mas que pressupõe de incorporação do capital cultural para a sua apropriação específica; c) no estado institucionalizado, em que o capital cultural mostra-se através de títulos, certificados e diplomas, em última instancia o Estado exerce o monopólio da violência simbólica, através da emissão de títulos (Bourdieu, 2005).
} 
Desse modo, devemos compreender que as instituições que possuem maior quantia de capital simbólico, como no caso da Igreja Católica no campo religioso brasileiro, impõem suas normas em torno da legitimidade religiosa, ao mesmo tempo em que, práticas tidas como não legítimas lançam mãos de estratégias que levam a um processo de proximidade, através da incorporação de elementos simbólicos, tidos como legítimos no campo. A incorporação das regras, que permite o norteamento das estratégias lançadas, se dá no chamado senso prático (Bourdieu, 1996, 2009). O senso prático resulta do processo de incorporação das "regras do jogo" em determinado campo, remete a uma série de conhecimento semiconscientes, que os agentes possuem no campo, que possibilita o norteamento das práticas destes agentes, em especial, para a manutenção e ampliação do volume de capital simbólico dos mesmos.

Considerando estes aspectos elencados, temos que, o sincretismo no Brasil direciona-se a partir de um processo pela busca de legitimidade social, o que implica, também, numa ascensão simbólica e social dos grupos envolvidos neste processo sincrético, já que, a aproximação de seus credos com às práticas legitimas implica, também, numa aproximação simbólica dos grupos socialmente privilegiados, o que se deve, à interdependência estabelecida entre os campos. De modo que, não podemos interpretar, o movimento do sincretismo, nem como uma ilusão de catequese (Nina Rodrigues, 2006), nem como um simples movimento de dominação cultural, uma vez que, sua elaboração está vinculada a uma complexo jogo de analogias (Bastide, 1985), que se associa às estratégias de sobrevivência cultural, e ascensão social, ainda que, não se pudesse haver um alteração em termos de classe social, já que a condição de escravizados lhes era imposta, o sincretismo abre uma possibilidade de ascensão, em termos de grupo de status (Weber, 1983).

Afora esta questão, há que se destacar que, estamos discorrendo acerca de uma nova realidade social, que implicou em mudanças na composição cosmogônica, dos grupos que aqui vieram. Com relação ao sincretismo, nas religiões afro-brasileiras, Souza (1986), retomando os argumentos já desenvolvidos por Bastide (1985), reali- 
za os seguintes apontamentos:

Para que pedir fecundidade às mulheres se, na terra do cativeiro, elas geravam bebes escravos? Como solicitar aos deuses boas colheitas numa agricultura que beneficiava os brancos, que se voltava para o comércio externo e não para a subsistência? 'Mais valia pedilhes a seca, as epidemias destruidoras de plantações, pois colheitas abundantes acabariam se traduzindo em mais trabalho para o escravo, mais fadiga, mais miséria'. A primeira seleção operada no seio da religião africana colocaria de lado as divindades protetoras da agricultura, valorizando em contrapartida, as da guerra - Ogum -, da justiça - Xangô -, da vingança - Exu. (Ibidem, p. 94)

Percebamos que, a constituição do universo religioso atrelase às condições sociais postas, não havendo, unicamente, uma esfera transcendente. A constituição religiosa reflete, desse modo, as condições objetivas de existência de determinado grupo social, ainda que, sua construção imaginária, traga, em si, um aspecto mais onírico, ligado ao ato de devanear e produzir construções mitológicas que permitam aos grupos ansiar por outra condição social, ainda assim, tal devaneio, atrela-se, também, a um contexto social específico.

Em todo o caso, a dinâmica do sincretismo demonstra as relações de poder postas, uma vez que, são os orixás que são mascarados com os santos católicos, não o inverso (Bastide, 1985), são os elementos da "identidade branca" que são assimilados pelos negros, levando a uma negação da própria identidade destes (Fanon, 2008), em todo o caso, toda dinâmica social mostra-se fluida, e apresenta várias direções, de modo que, o sincretismo não poderia ser entendido aqui como um movimento unilateral.

Algumas concepções de sincretismo trazem consigo a ideia de aculturação. Dentro da própria obra de Ramos, temos tanto uma concepção de aculturação que ocorreria de forma harmoniosa (Ramos, 1942), quanto uma concepção que coloca que o fenômeno da aculturação nem sempre se dá sem conflitos (Ramos, 1947). Já em Herskovits (1969), temos uma busca pelo avanço no debate, apontando 
que mesmo em contatos amistosos, como também em hostis, ocorre o fenômeno de aculturação, o autor ainda aponta para a possibilidade de ocorrer movimentos de contra-aculturação. Tanto em Ortiz (1999), quanto em Moura (1988), temos uma crítica ao conceito de aculturação. Para Moura, conceitos como sincretismo, assimilação, acomodação e aculturação, revelam o próprio papel da antropologia, como uma ciência auxiliar de uma estrutura neocolonizadora. Em todo o caso, o que nos interessa destacar aqui é, o fato de que o sincretismo não é um movimento de mão única, ao contrário coloca-se em meio às relações conflituosas de poder postas, numa dada sociedade.

Apesar da relevância das relações de poder, no processo de constituição do sincretismo, não só este aspecto deve ser trazido aqui, uma vez que há outros elementos, que estão atrelados, na constituição da realidade sincrética. Neste sentido, Motta (2000) realiza uma crítica, apontando para outros elementos, que estão ligados às mudanças mais gerais no sincretismo das religiões afro-brasileiras:

O sincretismo constituiu, nas décadas de 30 e de 40, um dos temas preferidos da pesquisa afro-brasileira ${ }^{4}$. A partir porém aproximadamente de 1970, a tendência principal dos pesquisadores ${ }^{5}$ vem sendo dar-lhe importância bem menor, sendo reinterpretado, de acordo com a sugestão de Bastide, como "máscara colonial". Pode-se, nesse ponto de vista, reconhecer a influência de um vago populismo de inspiração marxista, considerando os afro-brasileiros como uma espécie de classe oprimida, um proletariado que teria resistido ao opressor justamente pela religião, assimilada a uma pré-consciência de classe à qual não faltaria certo potencial revolucionário.

\footnotetext{
${ }^{4}$ Arthur Ramos (1940) e Waldemar Valente (1955) são exemplos eminentes da tendência filosincrética.

${ }^{5} \mathrm{O}$ exemplo arquetípico da tendência ânti-sincrética é o livro de Juana Elbein dos Santos (1976), o qual, desde seu aparecimento, não parou de influenciar a pesquisa afro-brasileira. De fato, muito antes que essa tendência se generalizasse entre os pesquisadores, a partir dos anos 70, ela já se encontrava nos trabalhos de Edison Carneiro (1936; 1937). Este autor, que não tem gozado da reputação que certamente mereceu, exerceu decisiva influência sobre Roger Bastide, o qual, apesar de seu "politeísmo" teórico e empírico, falava muito de "pureza africana" e considerava o candomblé como a sobrevivência, no Brasil, de uma África que coexistiria com a sociedade brasileira, mas sem jamais com esta fundir-se.
}

76| Século XXI, Revista de Ciências Sociais, v.3, nº 2, p.65-111, jul./dez. 2013 
Mas a verdade é que têm ocorrido transformações na vivência religiosa, as quais em grande parte se originam no próprio catolicismo, para o qual o culto dos santos se torna menos importante. Digamos então que, querendo-o ou não, a religião afro-brasileira se afasta da Igreja Católica, na medida justamente em que esta se afasta da religiosidade tradicional ibero-americana. Pois a Igreja repudia essa devoção largamente orientada para o alívio das aflições do quotidiano e volta-se --é eminentemente o caso da teologia da libertação-- para um projeto histórico de transformação da sociedade ${ }^{6}$. Ora, as ligações sincréticas do candomblé faziam-se essencialmente com o catolicismo popular, baseadas que estavam, ao nível das estruturas profundas, na equivalência entre o culto dos santos e o dos orixás. (Ibidem, p.4-5)

Sendo assim, para além das relações colonialistas, o sincretismo também deve ser pensado a partir de aspectos próprios do universo religioso, mas que, em todo o caso, ligam-se a dinâmica da sociedade envolvente, uma vez que, a introdução de elementos brancos, nos cultos das religiões afro-brasileiras, e, posteriormente, de brancos, propriamente ditos, vincula-se ao próprio processo de legitimação social do credo (ORTIZ, 1999).

Esta dinâmica, com relação à fluidez do sincretismo, nos leva a tecer algumas considerações, acerca do processo de constituição da identidade religiosa brasileira, que longe de perfazer de forma estanque, cristalizada, como poderia parecer a primeira vista, mostra-se plural, e em contínua transformação. Interessa-nos destacar a forma como as identidades religiosas se animam, e de como estas se relacionam com os dilemas da modernidade.

\footnotetext{
${ }^{6} \mathrm{Na}$ realidade, se bem que o distanciamento da Igreja com relação à religião popular se torne bem mais forte nas últimas décadas dos século XX, trata-se de processo bem mais antigo, ligado ao que Gilberto Freyre (1936) chamou a "reeuropeização" do catolicismo brasileiro, que já se evidencia a partir da segunda metade do século XIX. Essa ideia, retomada por Roger Bastide (1951), o qual prefere falar de "romanização" e depois por historiadores como Ralph della Cava (1970) e Thomas Bruneau (1970), tornou-se uma das ideias centrais da pesquisa histórica e sociológica sobre a religiosidade brasileira, conforme o exemplo de Pedro Ribeiro de Oliveira (1985). Ora, essa "reeuropeização", que atinge sobretudo o catolicismo de certa elite social e intelectual, levando-o a uma orientação mais ética e mais social, provoca indiretamente um vazio na religião popular, ocasionando o surgimento de outras igrejas ou para-igrejas, inclusive de um candomblé cada vez mais "reafricanizado", as quais tentam assumir a herança do antigo catolicismo tradicional.
}

77| Século XXI, Revista de Ciências Sociais, v.3, nº 2, p.65-111, jul./dez. 2013 ISSN: 2236-6725 
Muito conhecida é a afirmação de Latour (1994), que chega a colocar que nunca fomos modernos, na medida em que, as promessas da modernidade não se cumprem, ou ao menos não da forma como foram narradas. Para o autor:

Nosso passado começa a mudar. Enfim, se jamais tivéssemos sido modernos, pelo menos não da forma como a crítica nos narra, as relações tormentosas que estabelecemos com as outras naturezas-culturas seriam transformadas. O relativismo, a dominação, o imperialismo, a má fé, o sincretismo seriam todos explicados de outra forma, modificando então a antropologia comparada. (Ibidem, p.16).

Talvez, em termos de identidade religiosa, nós nunca tenhamos sido pré-modernos, na medida em que, uma concepção estanque de identidade, atrelada ao conceito de tradição, nunca se concretizou de fato. $\mathrm{O}$ sincretismo religioso colocou possibilidades ao sujeito pré-moderno, em termos de escolhas e possibilidades, além do que, o processo de negociação da realidade social leva os sujeitos a assumirem posições no campo religioso, e também político e social, em que a identidade é problematizada. No caso das religiões afro-brasileiras, mas também no caso dos cristãos novos no período colonial, mostra-se recorrente o processo de conversão, aspeada ou não, bem como a assimilação de uma dupla identidade, normalmente, uma pública e outra privada.

Novamente, voltamos aqui ao ponto das relações de dominação, existentes numa dada sociedade. No entanto, as posições e disposições assumidas no campo, no processo de dominação - que se expressa através da violência simbólica, em que aqueles que possuem maior quantia de capital simbólico, tanto incorporado, quanto objetivado e institucionalizado, apresentam posturas que visam reproduzir suas posições no campo - devem ser analisadas de maneira relacional, uma vez que, seu movimento, em torno da reprodução de uma determinada posição no campo, é também acompanhada de contra-movimentos, que visam uma mudança posicional no mesmo.

Nestes termos, o processo de articulação identitária, apre- 
senta-se como o delineamento de estratégias, que os atores sociais assumem, visando angariar uma maior quantia de capital simbólico. Considerando-se tal aspecto, as identidades não podem ser pensadas como estanques, já que, há um deslocamento no campo, que implica em outro estado e modo de ser no mundo.

Hall (2006) anuncia uma identidade pós-moderna, marcada por uma fragmentação de identidades, por vezes contraditórias, em posição a uma identidade moderna (iluminista), que pressupunha um sujeito:

[...] baseado numa concepção da pessoa humana como um individuo totalmente centrado, unificado, dotado das capacidades de razão, de consciência e de ação, cujo 'centro' consistia num núcleo inferior, que emergia pela primeira vez quando o sujeito nascia e com ele se desenvolvia, ainda que permanecendo essencialmente o mesmo - contínuo ou 'idêntico' a ele - ao longo da existência do indivíduo. O centro essencial do eu era a identidade de uma pessoa. (Ibidem, p. 10-11).

No entanto, esta identidade moderna, nunca se concretizou, de fato, em termos de identidade religiosa no Brasil, as tensões postas, bem como o próprio vacilar do ser, levaram a constituição de uma identidade religiosa conflitante, não só para aqueles que estariam numa posição de "dominação", lançados ao sincretismo estratégico, por vezes, como, também, para aqueles que pertenciam ao grupo "dominante", considerando que, mesmo o catolicismo existente no Brasil, sincretiza-se. Tanto que, sua prática distancia-se de um romanismo, ou mesmo de um ibericismo (Bastide, 1985; Freyre, 2006).

O peso da tradição, enquanto instância que cimentaria as práticas pré-modernas (Giddens, 1991, 1997, 2010), norteando os horizontes dos sujeitos, o que levaria a uma concepção de identidade assentada mais na permanência que na mudança, não se mostra real, ante ao cenário religioso brasileiro. Não estamos afirmando aqui, que a tradição não teve (e tem), um peso significativo sobre as escolhas identitárias dos sujeitos, ou sobre suas trajetórias no campo religioso, e nos diversos campos, mas reivindicamos aqui, outro olhar sobre a dinâmica das identidades religiosas no Brasil. 
Em verdade, o Brasil mostra-se extremamente singular, com relação a este ponto, pois, se temos, em alguns cenários, um processo de incorporação de identidades não herdadas, a partir de um contexto de secularização, de uma determinada sociedade, como no caso da França, trazido por Hervieu-Léger (2008), no Brasil, as possibilidades de assumir identidades não herdadas, se coloca num cenário em que a secularização não chegou às mesmas raias. Em todo o caso, isso não implica em dizer que, qualquer escolha é possível para qualquer sujeito, há possibilidades que são postas como mais prováveis, ou menos prováveis, a partir do lugar que o sujeito ocupa no espaço social.

Esta singularidade, no processo de formação e configuração do campo religioso, nos leva a reconhecer que, não apenas a pluralidade religiosa existente no Brasil impacta sobre a dinâmica das identidades, como também, esta impacta sobre tal pluralidade, sendo os dois fenômenos porosos entre si, estabelecendo uma relação complexa entre suas fronteiras. Interessa-nos destacar, portanto, como a questão da identidade religiosa se mostra singular, na realidade brasileira. Em especial como ela se relaciona com a dinâmica do sincretismo, que se mostra uma relevante estratégia simbólica e social de alteração da posição dos gentes sociais no campo, ainda que suas implicações caminhem para além de uma simples instrumentalização das práticas sociais.

\section{PROTESTANTES, ESPÍRITAS E OUTRAS VOZES DES- TOANTES}

Nossa exposição, até o momento, centrou-se na dinâmica do campo religioso brasileiro, focalizando o catolicismo e as religiões afro-brasileiras. Tais credos, em termos de estudos historiográficos, ou sócio-antropológicos, são aqueles que possuem uma esteira mais consolidada de pesquisas, no campo acadêmico. No entanto, há que se destacar que, em especial, a partir da segunda metade do século $\mathrm{XIX}$, início do XX, outros atores sociais passam a ganhar espaço na esfera pública brasileira, especificamente no campo religioso. Daremos enfase aqui, a duas práticas religiosas que mais que ganhar 
espaço, passaram a ser fundamentais para a compreensão da dinâmica religiosa brasileira contemporânea: $\mathrm{O}$ espiritismo e o protestantismo histórico ${ }^{7}$, que, apesar das divergências doutrinárias e de concepção de mundo, destacam-se por apresentar um estilo de vida marcadamente ascético e, também, pela singularidade que tomam no Brasil, e pela fragmentação ocorrida em termos de interpretação de seu corpus original.

Para Lewgoy (2004b), a questão do ascetismo no espiritismo kardecista no Brasil, ganha contornos mais claros na figura de Chico Xavier, que se dedica a divulgação do espiritismo, abdicando de qualquer luxo, ou dinheiro. Segundo o autor, o ascetismo do Chico Xavier, que se difunde como modelo ideal no kardecismo brasileiro, é um ascetismo "inter-mundano", nesta sua característica é que se manifesta de forma mais clara "renunciante" (ou do santo).

\section{OS ESPÍRITOS E O POVO BRASILEIRO: CONTINUIDA- DES E RUPTURAS NO KARDECISMO}

O espiritismo, enquanto doutrina religiosa, passa a ser divulgada no Brasil de forma quase simultânea que na França, de modo que no do século XIX, já havia seguidores no Brasil. Sua introdução se deu já em 1853, através das “mesas girantes”, em 1865, em Salvador, forma-se o primeiro grupo e o primeiro movimento espírita organizado no Brasil data de 1873, com a criação da Sociedade de Estudos Espíritas do Grupo Confúcio, no Rio de Janeiro. No entanto, as pesquisas em torno do mesmo são de data relativamente recente, na literatura sócio-antropológica (Stoll, 2002). A partir dos anos $60 \mathrm{e}$ 70 destacam-se os trabalhos de Bastide (1985[1960], 1967) e de Ca-

\footnotetext{
${ }^{7}$ No caso do protestantismo histórico devemos ressaltar que as práticas ascéticas não são homogêneas, muito pelo contrário, encontram-se em variados graus, segundo a denominação, o que se torna ainda mais claro com o movimento pentecostal. Em todo o caso, devemos destacar que tais elementos ainda apontam para uma prevalência, sobre tais elementos, em termos comparativos com outras religiões presentes no campo religioso brasileiro. Motta (2000) aponta para a oposição entre o transe presente nos cultos de candomblé, que representa a eclosão das emoções fundamentais do ser humano, ao passo em que, e o transe no culto protestante, que se baseia na negação de tais emoções e no controle ascético. De acordo com Mariano (1999), os neopentecostais rompem, justamente, com o ascetismo presente no pentecostalismo.
} 
margo (1961, 1973) que possuíam com questão de fundo a seguinte problematização:

[...] como explicar a difusão de religiões populares, especialmente o Pentecostalismo, o Espiritismo e as religiões afro-brasileiras, num contexto de aceleração do processo de urbanização? Ou em outros termos: como explicar a proliferação da religiosidade popular, tida como símbolo de "atraso", justamente no polo do desenvolvimento urbano e econômico do país, ou seja, no espaço social e simbólico tido como emblemático da "modernidade"? (Stoll, 2002, p. 365)

Esta questão mostra-se intrigante, na medida em que se volta para os próprios dilemas da modernidade e para a singularidade do campo religioso brasileiro enquanto espaço de contradições e de discursos entrecruzados. Há de se destacar o fato de que estamos nos referindo a uma religião que é trazida de um determinado contexto, e posto em outro, o que leva, obviamente, a formulação de novas práticas, bem como a adaptações simbólicas.

Tanto as análises de Bastide, quanto de Camargo, convergem para uma interpretação que compreende que, ao passo que o espiritismo na França possuiu uma dimensão predominantemente científica e experimental, no Brasil, a ênfase recaiu sobre o caráter religioso e místico.

Considerando-se o fato de que no Brasil, quando o Espiritismo é introduzido, ele encontra um campo religioso em que os cultos de possessão já são populares, em especial nas religiões afro-brasileiras, há um desenvolvimento de um diálogo profícuo, entre estes diversos cultos de possessão ${ }^{8}$, através da criação de proximidades e distanciamentos simbólicos. Para Brandão (2004), o candomblé, a umbanda e o espiritismo, formam no Brasil uma hierarquia simbólica entre as religiões de possessão, indo da mais negra a mais branca, da mais ligada à tradição oral àquela mais ligada à tradição escrita, e, consequentemente, da menos legítima a mais legítima. Destacase que, ao contrário dos demais cultos de possessão, o processo de erudição formal, marcado pela leitura sistemática, mostra-se como

${ }^{8}$ Para Aubrée e Laplantine (2009) há, no Brasil, uma verdadeira cultura dos espíritos.

82| Século XXI, Revista de Ciências Sociais, v.3, nº 2, p.65-111, jul./dez. 2013 ISSN: 2236-6725 
uma das principais demarcações identitárias do movimento espírita (Lewgoy, 2001; 2004a; 2004b; 2008), o que, atrelado ao fato de ser um movimento predominantemente de pessoas brancas, ao menos inicialmente, interfere no processo de legitimidade da religião no campo simbólico em que se insere, e por fim, destaca-se a centralidade na questão da caridade como ponto diferencial do movimento (Cavalcanti, 1983). Ainda que esta já esteja expressa no catolicismo, no espiritismo é apresentada de outra forma9.

Este movimento de proximidade e distanciamento liga-se às estratégias dos atores sociais no campo, na medida em que o processo de legitimidade social de determinado credo é constituído a partir das diversas disputas simbólicas em campo (Bourdieu, 2004b). Há, neste sentido, duas interpretações, mais recorrentes diferenciadas com relação à singularidade do espiritismo no Brasil. Para alguns autores (Camargo, 1963, 1971; Birman, 1996) o espiritismo demarca um continuu, com relação às religiões afro-brasileiras, ainda que haja uma variação com relação à interpretação e ao culto com relação à mesma estrutura cosmológica e experiência religiosa; já para outros (Maggie, 1992; Ortiz, 1999) o espiritismo constitui-se na formulação de uma religiosidade de possessão em oposição às religiões afro-brasileiras, seja com relação às suas características étnicas e sociais, como também, com relação a sua estrutura doutrinária.

No entanto, há que se destacar a própria proximidade com o catolicismo, uma vez que no Brasil, este credo, em especial na sua vertente popular, instaura uma intima relação com os espíritos, em especial com uma espécie de culto aos antepassados (Freyre, 2006). Para Brandão (1994), no Brasil há a constituição de um “código da alma”, marcado por diversas formas de se relacionar com os mortos, tal código seria:

Um sistema de valores e preceitos que define identidades e estabelece a norma de situações e princípios por meio dos quais pessoas vivas e a pessoa viva do morto podem viver entre elas: desejos, te-

\footnotetext{
${ }^{9}$ A caridade no espiritismo constitui-se como uma espinha dorsal para o movimento, na medida em que, através desta prática social (que se realiza tanto através de obras de assistência social, quanto espiritual), é que se viabiliza a evolução espiritual, tanto para os espíritos encarnados (em pessoas vivas), quanto os desencarnados (daquelas pessoas que já faleceram).
} 
mores, gestos e troca de bens, serviços e sentidos, em uma verdadeira lógica de reciprocidade (Ibidem, p. 182)

Sendo assim, ao chegar ao Brasil, o espiritismo encontra não apenas práticas de possessão estabelecidas nos cultos afro-brasileiros, como também, encontra uma religiosidade predominante, com maior peso sobre o campo religioso, em que a íntima relação com o "outro mundo", se dá de forma "natural", o que se mostra claro nas pesquisas envolvendo o catolicismo popular. Para Aubrée e Laplantine (2009), o espiritismo implicou numa ampliação, e sistematização, de uma "cultura dos espíritos", já existente no Brasil, marcada pela intimidade com os santos, eguns e orixás. Ramos (2001), já apontara para o fato de que havia uma afinidade entre o espiritismo e os cultos africanos, em especial os bantos, em que as práticas religiosas, deste grupo, assentavam-se, principalmente, no culto aos antepassados, ainda segundo o autor, o espiritismo fornece quadros de interpretação bastante coerentes, com relação às crenças de origem banto. Pires (2009), ao investigar o "mal-assombro", no Sertão do Nordeste No Brasil contemporâneo, acrescenta as diversas visões sobre a intervenção dos mortos no mundo dos vivos. Segundo a autora:

Para os católicos e os espíritas, por sua vez, o mal-assombro pode ser realmente a alma de uma pessoa falecida - muitas vezes, um parente. Neste caso, a alma do parente morto interfere - para o bem ou para o mal - na vida cotidiana da família que permanece viva. Quando uma alma interfere positivamente no dia-a-dia dos vivos, reconhece-se que ela já se encontrou no mundo dos mortos. (...) Parece-me que a aparição dos mal-assombros pode ser pensada como uma concessão divina em benefício dos vivos ou dos mortos pelos católicos e espíritas. Mas, para os crentes, diferentemente, não há alma que venha fazer o bem, porque todas elas são enviadas pelo Demônio. Mesmo que ela venha anunciando uma boa notícia, o bem vai reverter-se em mal posteriormente. (Ibidem, p. 294-195)

Esta ambiguidade, no que tange às relações estabelecidas com 
os espíritos, bem como a proximidade e o distanciamento, que se coloca em termos simbólicos, com relação às religiões afro-brasileiras, leva a uma criação categórica do chamado "baixo espiritismo". Para Maggie (1986, 1992), a criação dessa categoria começa a se delinear a partir de 1890, quando da criação do primeiro código penal republicano, onde o espiritismo foi incluído entre os crimes contra a saúde pública, no entanto, ao analisar os processos criminais, verifica-se que a condenação se dava em torno daqueles em que, no decorrer do processo, "verificava-se" que a utilização de tais práticas de dava para o "mal", ao passo que, aqueles que conseguiam convencer juízes, promotores e a opinião pública, que suas práticas eram utilizadas para o "bem”, tinham suas práticas legitimadas. Para Giumbelli (2003), “a expressão ‘baixo espiritismo’ passa a ser utilizada em determinado período histórico e está intimamente associada à criminalização das práticas espíritas, vigente em tal período”. (Ibidem, p. 249).

Estas relações, complexificam-se ainda mais, com a proximidade gerada entre o espiritismo e o candomblé, demarcada pela emersão da Umbanda no Rio de Janeiro, proclama, por alguns, como uma religião genuinamente brasileira. No entanto, Ortiz (1999), nos chama a atenção, para o movimento de "embranquecimento", dos cultos afro-brasileiros, que se deu não apenas através da incorporação de elementos do universo simbólico do branco, como também através da incorporação física, de pessoas brancas nos cultos dos orixás. A articulação, entre os elementos brancos e negros, se deu considerando as esferas valorativas, criadas pelas hierarquias simbólicas estabelecidas, entre estes dois polos sociais, na cultura brasileira, de modo que, segundo Ortiz (1999):

O que tentamos mostrar é que sempre existe a valorização do preto (e não do negro), ela se processa segundo a pertinência de uma cultura branca. Os elementos genuinamente africanos, ou melhor, afro -brasileiros, são rejeitados por esta camada de intelectuais, que são justamente os criadores da religião Umbanda. A cor preta é, desta forma, reinterpretada de acordo com os cânones de uma sociedade onde a ideologia branca é dominante. (Ibidem, p. 34) 
Voltamos ao ponto em que, as relações de poder, que se estabelecem numa dada sociedade, mostram-se fundamentais, para o processo interpretativo do campo religioso. Esta relação complexa, que se instaura no âmago do espiritismo brasileiro, o leva a ocupar uma posição singular, no campo religioso. Se para Bourdieu (2004a), a partir de uma releitura da obra de Weber, o campo religioso se coloca entre polos bem demarcados, tensionados entre: o sacerdote, representante da religião institucionalizada; o profeta, representante da religião emergente; e o mago, que oferece serviços espirituais. Caberia aos leigos, o papel de se deslocar entre estes polos.

O espiritismo assume uma posição singular, ao mesmo tempo, apresenta-se como uma "seita", no sentido de religião emergente, institucionaliza-se se tornando uma religião, no entanto, perfazendo a oferta de serviços espirituais, o que constitui o alicerce de sua prática da "caridade", destacando-se a sua dimensão terapêutica, tanto no âmbito da cura, quanto do conforto espiritual.

Além disso, a partir da segunda metade do século XX, percebemos diversas aproximações que o espiritismo estabelece, tanto com o catolicismo, como com a ciência e com a Nova Era. Tais aproximações se dão a partir de figuras emblemáticas, e icônicas do movimento, como no caso mais destacado que é o Chico Xavier ${ }^{10}$, que apresenta uma aproximação clara com o catolicismo, seja no âmbito da linguagem de suas cartas biografadas, bem como através de sua narrativa biográfica, de caráter eminentemente hagiográfico. Ao passo que, com Waldo Vieira ${ }^{11}$, o espiritismo experimenta uma "reaproximação", com as experiências de caráter "científico" e "experimental", através das chamadas paraciências. E, por fim, através do Luiz Antonio Gasparetto ${ }^{12}$, há o delineamento de uma aproxima-

\footnotetext{
${ }^{10}$ Francisco de Paula Cândido Xavier (1910-2002), foi um dos principais divulgadores da doutrina espírita no Brasil, e considerado um dos maiores médiuns do século XX. Seu trabalho mediúnico ganhou visibilidade através das cartas psicografadas, e dos livros, também psicografados, que contabilizam mais de 400 títulos.

${ }^{11}$ Waldo Vieira (1932) é um pesquisador independente, e propositor da Projeciologia e da Conscienciologia, tornou-se conhecido por ser um médium parceiro de Chico Xavier, hoje, mais conhecido como um dissidente espírita, e pesquisador da projeção da consciência.
}

${ }^{12}$ Luiz Antonio Alencastro Gasparetto (1949), tornou-se conhecido através da exibição de pinturas mediúnicas, atribuídas a grandes mestres das artes plásticas, a partir dos anos 80 do século XX, 86| Século XXI, Revista de Ciências Sociais, v.3, nº 2, p.65-111, jul./dez. 2013 ISSN: 2236-6725 
ção com o discurso presente nos livros de auto-ajuda, e do caráter hibrido da Nova Era (Stoll, 2002).

Para D’Andrea (2000), o aumento do número de adeptos do espiritismo, no Brasil, se viabilizou, dentre outros fatores, através, justamente, desse processo de fragmentação, que possibilitou a formulação de quadros interpretativos e significativos para diversas realidades sociais. Destacamos, por fim, que o espiritismo não apenas recebeu diversas influências, em decorrência dos enésimos contatos com as várias práticas religiosas existentes, como também imprimiu características próprias ao campo religioso brasileiro, sistematizando o contato com os espíritos, bem como, deu outra conotação ao processo de possessão, buscando desvincular do "baixo espiritismo", presente nos cultos das religiões afro-brasileiras, articulando uma dimensão tanto étnica, estética, quando ética, a partir de uma prática religiosa claramente ascética.

\section{CRENTES, EVANGÉLICOS, PENTECOSTAIS E OUTRAS DENOMINAÇÕES: PROTESTANTISMO E PLURALIDADE NO BRASIL}

Os estudos em torno das denominações cristãs não católicas, cujas raízes históricas remetem à Reforma iniciada por Calvino, e por Lutero, no século XVI, tem sido um objeto de especial apreço às ciências sociais Weber, em A Ética Protestante e o Espírito do Capitalismo (2004), o ethos religioso protestante é explorado, na medida em que, o autor realiza uma interpretação original acerca da gênese do capitalismo moderno, atrelando seu surgimento ao modo de ser no mundo protestante, que norteado por uma ideia de predestinação, cria angustias ao crente, que busca no mundo os sinais de sua salvação, o que reverbera em práticas ascéticas de fundamental importância para a elaboração de um capitalismo racional.

Holanda, em Raízes do Brasil (1995), contrapõe nossa tradição cultual com aquela presente nos países nórdicos de tradição protestante, apontando para o fato de que, nossa mentalidade seria 
avessa às práticas do associativismo racional, típicas dos países de tradição protestante, nós apresentaríamos, portanto, uma cultura “individualista amoral". Faoro, em Os Donos do Poder (1984), também aponta para uma relação que se estabelece de forma antinômica, entre um ethos ibérico católico, e um ethos nórdico protestante, na medida em que, busca explicar a dimensão das problemáticas sociais brasileiras, a partir de uma interpretação que se baseia na herança patrimonial lusa, que, implicariam num Estado estamental e centralizador, que favoreceria a emergência de um capitalismo comercial, ao passo em que, sendo o Estado Inglês, avesso ao centralismo e à burocracia, este refletiria, de forma mais precisa, os interesses da sociedade, viabilizando o capitalismo industrial. Mais sutil é a referência a Weber na obra de Freyre, que na apreensão de Motta (2008), demonstra como Freyre ao desenvolve a ideia de um "tempo ibérico", de inspiração franciscana, em oposição à lógica racional nórdica protestante, demarcando uma diferenciação de caráter histórico cultural do Brasil, e da América Latina de modo geral, com relação ao s países de colonização protestante.

No entanto, ao transpormos a teoria weberiana para o caso brasileiro, incorremos num diálogo com sobressaltos. Souza (1998) realiza uma crítica à possibilidade de universalidade da análise weberiana, ao apontar que, ao realizarmos uma análise tomando a investigação weberiana como absoluta, deixamos implícito o que é atrasado ou avançado, tradicional ou moderno, e perdemos e real dimensão da noção de ambiguidade cultual, tal noção, segundo o autor, percebe qualquer escolha cultural contingente como envolvendo, simultaneamente, perdas e danos.

Em todo o caso, interessa-nos demonstrar aqui, o fato de que, apesar de parecer, por vezes, um campo de estudo novo, nas ciências sociais brasileiras, que ganha fôlego em especial a partir da visibilidade que o protestantismo toma a partir dos anos 80 e 90, às referências a investigação, em torno do protestantismo, remete a uma tradição muito mais profunda, tendo, possivelmente, como grande sustentáculo a obra de Weber. No entanto, o protestantismo atingiu no Brasil uma pluralidade, que possivelmente, a imaginação socio- 
lógica de Weber não teria atingido.

A grosso modo, fala-se no Brasil de Protestantismo missionário, ou histórico, pentecostalismo, e neopentecostalismo, que possuem singularidades e contornos bastante próprios. Bittencourt Filho (2003), ao buscar delinear o percurso histórico do protestantismo no Brasil, aponta para o fato de que, o protestantismo missionário, ao chegar nestes lados do Equador, buscou realizar uma prática, que se afastasse da sincrética matriz religiosa brasileira. Segundo o autor:

Por mais de um século, o protestantismo tradicional tem tentado sepultar a Religiosidade Matricial por meio de uma espécie de pietismo racionalista, ou seja, uma religiosidade subjetiva e individualista, porém muito bem delineada, nos seus contornos, pela rigidez doutrinária e pelo fundamentalismo bíblico. Essa tentativa frustrada produziu pelo menos três efeitos: um projeto eclesiológico consoante aos princípios básicos da Reforma do século XVI tornou-se inexequível no campo religioso brasileiro,; a relevância e a pertinência do protestantismo missionário permaneceu restrita a um período histórico; e o espaço deixados pelo denominacionalismo importado dos Estados Unidos foi ocupado pelos pentecostalismos, uma vez que estes dispensaram um tratamento mais adequado à Matriz Religiosa Brasileira e obtiveram assim maior receptividade por parte das massas ao demonstrarem sua capacidade de adaptação à realidade cultural pátria. (Ibidem, p. 89)

Percebe-se, desse modo, que o diálogo com os aspectos singulares do campo religioso brasileiro, mostra-se necessário, para o processo de consolidação de determinado credo. Neste caso, temos que, o processo de angariamento de capital de simbólico, pressupõe estratégias que considerem as disputas simbólicas em curso, ou seja, a incorporação, ou modelação, do ethos religioso se faz necessário, enquanto forma de capital simbólico legítimo existente no campo, sem este processo de incorporação, que perpassa o âmbito doutrinário, gestual, linguístico etc., o credo emergente continua sem legitimidade social, e seus bens de salvação, que passam a ser ofertados 
no campo religioso, não se tornam objeto de procura por parte dos leigos, o que implica num número menor de conversões, e, consequentemente, implica em uma igreja mais vazia de fiéis.

Para Mendonça (1994), a mensagem do protestantismo histórico pode ser vista como uma "reserva religiosa", que encontrou espaço junto a uma "situação-limite", ou seja, junto a um extrato específico da população, sem rumo ou horizonte, no entanto, tal protestantismo foi incapaz de manter sua "reserva religiosa," e perceber as novas "situações-limite", que tomavam corpo num país em processo de urbanização, de modo que, seu espaço foi tomado cada vez mais pelo pentecostalismo, que passa a incorporar elementos místicos, simbólicos e mágicos, existentes no campo religioso brasileiro.

O que se percebe, é que, da mesma forma que no caso do espiritismo kardecista, a introdução de uma prática religiosa, que estava alicerçada num projeto racionalista de religiosidade, não encontra o espaço amplo para a sua proliferação e legitimação. Considerandose o processo histórico de configuração do campo religioso brasileiro, nota-se a preponderância do fator emotivo, sobre a racionalidade do sagrado, ainda que, se possa articular a emotividade com um discurso racional, em que, as características modernas ganham destaque. Segundo Silva (2006), a fase iniciada a partir dos anos 70, do século XX, com a emergência do neopentecostalismo, foi marcada por características singulares.

Pelo acréscimo do prefixo latino 'neo', pretendeu-se expressar algumas ênfases que as igrejas identificadas nesta fase assumiram em relação ao campo do qual, em geral, faziam parte: abandono (ou abrandamento) do ascetismo, valorização do pragmatismo, utilização de gestão empresarial na condução dos templos, ênfase na teologia da prosperidade, utilização da mídia para o trabalho de proselitismo em massa e de propaganda religiosa (por isso chamadas de 'igrejas eletrônicas') e centralidade na teologia da batalha espiritual contra as outras denominações religiosas, sobretudo as afro-brasileiras e o espiritismo. (Silva, 2006, p. 208) 
A dinamicidade, dos cultos neopentecostais, pontua-se em oposição aos demais credos já estabelecidos no campo religioso, demarcando também um status de "modernos", desse modo, passa-se a ofertar novos bens de salvação, que se diferenciam simbolicamente daqueles já oferecidos. O que em parte, já havia sido utilizado pelo espiritismo. Pois como nos pontua Sanchis (2001) “[...] a partir do advento do pentecostalismo, o jogo do 'trânsito' se pluralizou em várias dimensões no interior do campo cristão.” (Ibidem, p. 15).

Assim, o kardecismo, com sua incorporação controlada, suas mensagens psicografas, se coloca em oposição à incorporação festiva, emotiva e oral existente nos cultos afro-brasileiros, demarcando uma antinomia que, em ultima instância, polariza o "atrasado" e o "moderno", onde o moderno é o próprio sagrado, e o atrasado é o profano, o "baixo espiritismo", que não pode ser sagrado. Da mesma forma, o pentecostalismo traz os elementos cristãos, uma demarcação simbólica de continuidade, mas que com suas práticas ascéticas, suas indumentárias sagradas que não se afastam dos "homens do povo", ao contrário das vestes do pároco claramente sacerdotais, aproximando-se de um aspecto visual símile da pequena burguesia, que avançava pelas cidades. Em ambos os casos, há uma representação clara de antinomia com relação a um credo estabelecido, atrelando este ao rural, o atrasado, o passado, e, no final das contas, ao "não sagrado", ao passo que se afirmam como representantes do urbano, do moderno, do presente (e futuro), e, no final das contas, do "verdadeiro sagrado". Mas também suas práticas denotam uma continuidade, em termos simbólicos e identitários, cuja dinâmica está assentada, de forma inegável, no sincretismo religioso.

As práticas emotivas do neopentecostalismo, a glossolalia ${ }^{13}$, acompanhados de elementos como a demonização do mundo (estar no mundo, mas não ser do mundo, para o crente), e, posteriormente, a chamada teologia da prosperidade ${ }^{14}$, demarcam recurso identitá-

\footnotetext{
${ }^{13}$ A glossolalia remete a uma prática religiosa, em que o indivíduo, geralmente em estado de êxtase religioso, acredita expressar-se através de uma língua por ele desconhecida, cuja origem seria divina.

${ }^{14}$ Teologia da prosperidade, também conhecida como confissão positiva, palavra da fé, movimento da fé e evangelho da saúde e da prosperidade, é um movimento religioso surgido nas primeiras décadas do século XX nos Estados Unidos. Sua doutrina afirma, a partir da interpretação de alguns 91| Século XXI, Revista de Ciências Sociais, v.3, nº 2, p.65-111, jul./dez. 2013 ISSN: 2236-6725
} 
rios diversos, para Motta (2007), estas religiões encontram-se, em termos éticos e morais, em uma singular afinidade com a modernidade, seja pelo pragmatismo, seja pelo próprio processo de desculpabilização das práticas dos sujeitos, que ao se converterem encontram as reais razões de seus equívocos, que, necessariamente, encontramse fora dos sujeitos, no mundo, ao qual o crente não deve pertencer.

Hoje, certamente, as pesquisas em torno do pentecostalismo, e neopentecostalismo, têm atraído a atenção dos mais diversos pesquisadores, trabalhos como os de Mariano (1999a, 1999b, 2006, 2011), Oro (2003, 2010), Campos e Gusmão (2008), Burity (2006, 2011), Giumbelli (2002), têm se mostrado frutíferos no sentido de explorar a analisar a dinâmica dos movimentos pentecostal e neopentecostal brasileiros, demonstrando sua articulação com outros campos, como o político, social e cultural, bem como a forma como tais credos se articulam, em termos de discurso e de prática, com a pluralidade religiosa existente no país.

\section{NOVAS ESPIRITUALIDADES NUM MUNDO (DES/RE) ENCANTADO}

Como já apontamos, Bourdieu (2004a), busca realizar uma análise acerca da estrutura e da gênese do campo religioso, partindo da obra de Weber, sendo uma das figuras centrais neste campo o profeta, que será aquele que anuncia a vinda de uma nova prática religiosa, através de seu carisma, fundando assim a seita, em oposição à religião institucionalizada, comandada pelo sacerdote. Em Weber (1999) encontramos a seguinte definição de profeta:

Por "profeta" queremos entender aqui o portador de um carisma puramente pessoal, o qual, em virtude de sua missão, anuncia uma doutrina religiosa ou um mandato divino. (...) $\mathrm{O}$ decisivo para nós

textos bíblicos como Gênesis 17.7, Marcos 11.23-24 e Lucas 11.9-10, que os que são verdadeiramente fiéis a Deus devem desfrutar de uma excelente situação na área financeira, na saúde, etc. No Brasil, muitos pesquisadores têm se utilizado deste termo para se referirem aos cultos pentecostais, de modo geral, que tomam a prosperidade financeira como principal "marketing" de suas denominações. 
é a vocação 'pessoal'. Esta é que distingue o profeta do sacerdote. Primeiro e sobretudo porque o segundo reclama a autoridade por estar a serviço de uma tradição sagrada, e o primeiro, ao contrário, em virtude de sua revelação pessoal ou de seu carisma. (...) Este se distingue do mago pelo fato de que anuncia revelações substanciais e que a substância de sua missão não consiste em magia mas em doutrina ou mandamento.” (Ibidem, p. 303).

Mas ao contrário de Weber, Bourdieu (2004a), não percebe o profeta como o homem extraordinário, mas sim, como o homem das situações extraordinárias, atrelando, desse modo, a dinâmica, presente nos movimentos religiosos emergentes, às transformações mais amplas na sociedade envolvente. Interessa-nos aqui destacar tal esfera, na medida em que, compreendemos que o surgimento de novas religiosidades, e espiritualidades, no mundo contemporâneo se inserem num quadro de análise muito mais amplo, que se articula tanto às características singulares da modernidade, como também à globalização, enquanto fenômeno social moderno singular.

Oliveira (2007), ao se apropriar criticamente da obra de Bourdieu, aponta para as limitações da análise do autor, especialmente no que tange à sua compreensão do lugar do leigo no campo religioso. Segundo Oliveira:

Bourdieu chama a atenção para este fato ao afirmar que os leigos são condenados à condição de consumidores, mas deixa de lado que só é expropriado quem produz. Ora, os 'leigos' na verdade são produtores de bens religiosos, sim, mas anônima e coletivamente. As significações religiosas por eles produzidas ficam em estado bruto até que os especialistas trabalhem, lapidando-as para apresentarem como se fossem uma intuição ou uma revelação original. (Ibidem, p. 191).

A crítica de fato é pertinente e relevadora, no entanto, ela incorre no mesmo equivoco que produziu a fissura na análise tanto weberiana como bourdieusiana: a atemporalidade. Tanto em Weber, como em Bourdieu, dentre outros autores, encontramos um esforço in- 
telectual para a apreensão do fenômeno religioso em sua totalidade, de modo que, os modelos analíticos, assumidamente limitados enquanto tipo ideais, incorrem no equivoco de pensar o campo in illo tempore, como se não houvesse uma dimensão diacrônica na dinâmica do religioso, como se, ontologicamente a dinâmica do sagrado não pudesse ser pensado em termos contingenciais. O modelo heurístico criado é brilhante, no entanto, limitado em termos de tempo e de espaço.

A crítica de Oliveira, como já afirmamos, é pertinente, porém padece do mesmo mal, trata a religião de forma estática. A produção religiosa por parte dos leigos, nos remete a uma dinâmica moderna da religião, que não pode ser pensada como universal em termos temporais ou espaciais, sua crítica, neste sentido, mostra-se eficaz em termos parciais, adentrando nas fissuras que escapam à construção intelectual, presentes em Weber e em Bourdieu. Até mesmo porque, o leigo produtor de significações religiosas, ao qual Oliveira se refere, é, essencialmente, o indivíduo moderno, e como tal, datado enquanto invenção social, em oposição a uma teoria de campo, que estaria disposta a pensar a religião em termos mais amplos, indo para além do período moderno.

A compreensão acerca da dinâmica dos Novos Movimentos Religiosos - NMR - que emergem no cenário atual, deve considerar tanto os aspectos singulares do campo religioso, como também, o aspecto contingencial e histórico da realidade religiosa, que se atrela, como já apontamos, a aspectos mais amplos da sociedade envolvente.

Quando Berger (1985) analisa o processo de secularização nas sociedades modernas, pontuando, que, por um lado, há um processo de privatização da religião, reduzindo-a ao indivíduo, ou a pequenos grupos, e por outro, o surgimento de um pluralismo religioso, resultado da ruptura do monopólio religioso, e a instauração de um processo de competição definições distintas da realidade, há, ao fundo, uma compreensão do fenômeno religioso que só se faz possível a partir de invenção moderna do indivíduo. Para Herveu-Léger (2008):

Esta questão de uma 'religião à escolha', que pressupõe a experiência pessoal e a autenticidade de um percurso de conhecimento, ao invés 
da cuidadosa conformação às verdades religiosas asseguradas por uma instituição, é coerente com o advento de uma modernidade psicológica que exige, de certa maneira, que o homem se pense a si mesmo como individualidade e trabalhe para conquistar sua identidade pessoal, além de toda identidade herdada ou prescrita. (Ibidem, p. 60-61).

Sendo assim, a singularidade das mudanças no campo religioso, que reverbera nas práticas dos sujeitos, remetem a uma concepção específica de modernidade. Ao mesmo tempo, podemos, e devemos, reconhecer que há elementos intrinsecamente ligados à idiossincrasia do campo religioso, uma vez que, houve e hão de haver profetas, ofertando novos bens de salvação, no entanto, o escopo e conteúdo de suas revelações remetem a outra interpretação de significados, e outras construções simbólicas, por exemplo, é no cenário moderno que a tradição passa a ser utilizada de forma mais performática, enquanto elemento a ser reelaborado e utilizada como instrumento de legitimação. Como, é o profeta moderno que estará especialmente atento às diversas "províncias de significado", as respostas de sua profecia remetem mais focalmente a respostas direcionadas aos problemas do self, ainda que tais problemas remetam a uma reconexão com a comunidade, esta, outrora, foco do profeta pré-moderno.

Este indivíduo moderno, recortado por elementos como gênero, classe, cor, lugar etc, ao se deslocar e transitar no campo religioso, passa não só a formular novas práticas e significações religiosas, como também, passa a buscar novas possibilidades de gerações de sentido, institucional, ou não. Hervieu-Léger (2008), ainda aponta para as possibilidades abertas pela modernidade, tanto no sentido de se pertencer sem crer, como no sentido de se crer sem se pertencer, demonstrando um contínuo processo de autonomização, entre a esfera da produção de significados e a institucional.

A proliferação de instituições, e de experiências religiosas, nos remete ao conceito de "seita", explorado também por Weber, a qual, além de ser fundada pelo profeta, estaria em oposição à Igreja, singularmente situada a partir de características tanto organizacionais quanto ideológicas, apresentando-se de forma hostil ou indife- 
rente ao "mundo". No entanto, ao nos remetermos ao universo religioso contemporâneo, em especial ao que tange os NMR, temos um novo cenário, para Giumbelli (2002):

A partir da noção de NMRs, não só esse padrão organizacional e ideológico dá lugar a uma diversidade de possibilidades, como também a 'tensão com o mundo' deixa de ser vista enquanto uma característica intrínseca do grupo e passa a depender de reações sociais que ele encontra. (...) Neste sentido, as controvérsias que os NMRs geram constituem um revelador privilegiado para padrões, normas, valores vigentes na sociedade que os abrigam. (Ibidem, p. 19)

Encontramo-nos, portanto, em um cenário em que a relação que os credos emergentes estabelecem relações das mais diversas com o mundo. Isto inclui a própria relação com a secularização, do mundo moderno, na medida em que, o pluralismo religioso, e o escopo que as mudanças no campo religioso apresentam, remetem a uma aparente contradição com a ideia de "secularização", normalmente entendida como perda de significância social das motivações, atividades e instituições religiosas (Wilson, 1987).

Ainda que haja divergência, sobre o vulto do recuo do domínio do religioso nas sociedades contemporâneas, as pesquisas convergem em apontar para o fato de que, a religião deixa de ser a instância integradora da sociedade, perdendo função e poder (Giumbelli, 2002). Tal recuo implica, tanto numa fragmentação institucional, que se expressa através do pluralismo religioso, quanto num recuo da esfera pública para a esfera subjetiva, o que se expressa através da individualização da experiência e do pertencimento religioso. Claro que tal cenário tanto é contextual, variando de sociedade para sociedade, como também não é linear, pois, ao mesmo tempo em que, as sociedades modernas organizam-se a partir de instancias seculares autônomas, como o Estado e o Mercado, os indivíduos presentes nas mesmas podem cultuar uma infinidade de deuses (Steil, 1993).

Alguns autores remetem suas análises a um suposto "reencantamento" do mundo, ao perceber a visibilidade que o fenômeno 
religioso toma, no mundo contemporâneo, em especial, na segunda metade do século XX, como demonstra Beger (1970). Outros, ao pensarem este mesmo fenômeno, situam que não podemos falar verdadeiramente em reencantamento, tendo em vista que o mundo nunca esteve desencantado (Guerriero, 2006).

Estes novos contornos da realidade religiosa, se expressam tanto no nível de uma pluralidade religiosa que se assenta através a emergência de novas religiosidades, como também na proliferação de modos de ser e de sentir dentro das religiões já institucionalizadas, como no caso emblemático do catolicismo:

As opções para expressar o "ser católico" se multiplicaram nestes últimos anos, de modo que as suas possibilidades podem variar das formas mais tradicionais às mais politico-libertárias ou emocional-carismáticas. Alguns podem ser católicos, centrando sua prática no culto aos santos, outros participando de associações religiosas, outros ainda assumindo compromissos éticos e políticos de caráter libertário. E há também aqueles que se consideram católicos, sem que isto os vinculem a quaisquer compromissos explícitos de ordem religioso-institucional. (Steil, 2001, p. 117).

Estes novos contornos, que toma o fenômeno religioso nas sociedades contemporâneas, assume uma postura ainda mais singular junto ao campo religioso brasileiro, permeado por uma intensa pluralidade religiosa, mesmo ante a um cenário não secularizado.

Esta pluralidade religiosa no Brasil implica, por um lado, num processo de bricolagem subjetiva religiosa, em que os sujeitos, a partir de suas diversas experiências com o sagrado, formulam uma possibilidade de experimentação religiosa singular, que se atrela à totalidade simbólica do grupo em que o sujeito se insere, de forma, mais ou menos estável, variando de acordo com a posição que o sujeito ocupa no espaço social, ou seja, a partir das múltiplas posições que o mesmo ocupa no campo (Bourdieu, 2005). Por outro lado, cria-se um intenso fluxo e refluxo religioso, através do trânsito que se estabelece entre os agentes sociais, os mesmos deslocam-se pelos diversos credos, e 
os credos também se deslocam pelos diversos sujeitos, em meio a um cenário de competição religioso, numa busca ávida por fieis.

Ainda que neste cenário de competição, e de mercado religioso, haja uma intensa racionalização na forma de gerir o sagrado, por parte das instituições e atores religiosos, percebemos uma preponderância do elemento emotivo como motor da vivência religiosa, as "novas formar de sentir" ainda situam seu foco muito mais no "sentir", que no "novas". Isto implica, também, numa aproximação entre a religião e magia, contrariando o argumento de Durkheim (2003), as igrejas mágicas se proliferam. Considerando-se que a ação mágica é racional, porém não a partir de uma relação entre meios e fins, mas sim pela experiência (Weber, 1999), sua articulação no plano das religiosidades institucionalizadas se faz não só possível, como mesmo predominante.

A profusão dos NMRs no Brasil se dá, portanto, a partir de uma lógica já apresentada no que tange à difusão do espiritismo e do pentecostalismo no Brasil, desenvolvendo um aspecto místico, extático, emotivo e terapêutico, em preponderância com relação a uma racionalização do sagrado, ainda que este elemento possa se fazer presente enquanto instância de legitimação institucional.

Ainda que, por vezes, possa ser demarcada uma fronteira simbólica entre os NMRs e as religiosidades populares, percebemos que se estabelece uma continuidade em termos de lógicas de pertencimento e composição ritualística, como nos demonstra Silva (2006), ao apontar as proximidades e distanciamentos com relação à Igreja Universal do Reino de Deus e os cultos afro-brasileiros.

Interessa-nos aqui destacar, que a profusão de NMRs no Brasil, seja através da difusão de novas denominações pentecostais e neopentecostais, ou através de novas vivências no catolicismo, como o caso do movimento carismático, ou mesmo através de novas sínteses originais, como no caso das religiões da ahyuasca ${ }^{15}$, demarca um pro${ }^{15}$ A ayahuasca refere-se a uma bebida, produzida a partir da do cipó do Banisteriopsis caapi e das folhas do arbusto da Psychotria viridis, utilizada em como bebida ritualística por diversos grupos indígenas. Ganha visibilidade quando a passar a ser utilizada através de práticas sincréticas, tornando-se a parte central do ritual do Santo Daime, religião fundada no início do século XX, no Acre, por Raimundo Irineu Serra. Também é parte central no ritual da União do Vegetal e da Barquinha, ambas fundadas no Acre. 
fundo processo de mudança mais ampla na sociedade brasileira, que possibilita ao mesmo tempo o questionamento das práticas religiosas institucionalizadas, situando-se numa posição crítica com relação a estas, bem como a utilização de elementos presentes na mesma.

A dinâmica de tais movimentos, expressa, tanto as transformações no nível da subjetividade e da identidade dos sujeitos, como também, as novas formas de se relacionar com a comunidade, como também, com a sociedade mais ampla.

\section{CULTURA ESOTÉRICA E NOVA ERA NO BRASIL}

As pesquisas envolvendo o fenômeno religioso, têm estado tensionadas entre a dimensão do sujeito e da comunidade, ou da sociedade quando o caso, com uma leve preponderância para os estudos que enfatizam esta última esfera. O seu caráter congregacional foi destacado, por autores como Durkheim (2003), bem como Parsons (1974), que situa a religião no subsistema cultural, ligado aos valores, segundo o autor "Em última análise, os valores são legitimados principalmente em termos religiosos" (Ibidem, p. 21), são, portanto, um importante instrumento de socialização do sujeito, que faz ele pertencer a uma dada sociedade.

Este caráter congregacional passa a ser relativizado, com a emersão do sujeito moderno, que longe de ser algo universal, é uma inversão recente, como aponta Foucault (1999), a partir deste momento, a religião, além de possuir um caráter ligado ao processo de socialização, passa, também, a substanciar a construção da identidade individual dos sujeitos, ainda que, possamos também falar da crise das instituições tradicionais geradoras de sentido (Brandão, 1994), o que leva tais sujeitos a busca de outras alternativas, outras construções simbólicas, que lhes deem sentido.

A totalidade simbólica, representada pelo cristianismo no ocidente, passa a não ser mais a única alternativa religiosa, em especial com o advento da globalização (Ortiz, 2001), não apenas outras expressões religiosas, que já existiam, ganham relevo, como há, também, uma profícua emersão de outras novas religiosidades. 
Na passagem do século XIX para o XX, práticas milenares passam a ser reavivadas. $\mathrm{O}$ ocultismo e o esoterismo europeu, em especial, passam a ser reanimados, longe dos olhos inquisidores e onipresentes da Igreja, ainda que, se possa questionar o papel do Estado, tido como laico neste e em outros momentos. Porém tais práticas, obviamente, reemergem com uma nova roupagem, e seu caráter iniciático e velado passa a ser cada vez mais aberto, não se trata agora, apenas do pertencimento estrito a determinado movimento ocultista e/ou esotérico, mas sim no centramento no self, no autoaperfeiçoamento da pessoa humana (Silva, 2000).

Quando centramos nossa análise na ideia de reavivamento, entendemos,com isso, que não estamos falando de uma transmigração automática, entre o chamado esoterismo europeu e as práticas vivenciadas no século XIX e XX, até mesmo porque, devemos considerar o impacto de fatores como o advento da modernidade e a globalização, estes intimamente ligados. Além do mais, no campo de estudo das religiões o esotérico tem se referido, majoritariamente, aos ritos e elementos doutrinários reservados aos membros admitidos a um centro mais restrito, ao passo que, exotérico tem se remetido à parte pública do cerimonial (Boas, 1994).

Além do mais, no bojo das transformações, aos quais estamos nos referindo aqui, o esoterismo e o ocultismo europeu são apenas dois elementos trazidos para a formulação de uma "nova gnose" (Mello, 2004). Devemos acrescer, a esta formulação, a influência do transcendendentalismo americano ${ }^{16}$ do século XIX, e da teosofia ${ }^{17}$, desenvolvida por Helena Blavastsky, Henry S. Olcott e Annie Besant.

Com o advento do movimento de contracultura ${ }^{18}$ e o conse-

\footnotetext{
${ }^{16} \mathrm{O}$ transcendentalismo refere-se a um grupo de novas ideias, surgidas na Nova Inglaterra, em meados do século XIX, que prega a existência de um estado espiritual que "transcende" do físico e o empírico.

${ }^{17}$ Remete a uma série de conhecimentos, que visa integrar religião, filosofia e ciência. É definida por Helena Blavatsky como o conhecimento divino, ou a ciência divina. Traz elementos orientais, para buscar a realização de uma "religião universal". Foi amplamente divulgada pela obra de Blavatsky através de livros como Ísis sem Véu (1877) e A Doutrina Secreta (1888).

${ }^{18}$ Contracultura é um movimento, relativamente difuso, que teve seu auge nos anos 60 , do século XX, tinha como principal base de sustentação, a contestação dos valores sociais de sua época, seu principal bojo, em termos de emergência e de desdobramentos, é nos Estados Unidos, ganhando uma especial visibilidade ante a Guerra do Vietnã.
}

100| Século XXI, Revista de Ciências Sociais, v.3, nº 2, p.65-111, jul./dez. 2013

ISSN: $2236-6725$ 
quente aumento do fluxo entre Oriente e Ocidente, com a "invasão dos gurus" no mundo ocidental, juntamente com suas filosofias orientais, ou de inspiração oriental, o movimento toma feições mais claras, que se delineiam ainda mais com a infiltração dos discursos de caráter científicos (ou pseudo-científico como colocam alguns), tendo como um dos marcos, a publicação de Fritjof Capra O Tao da Física (1974).

Estamos lidando, portanto, com a uma miríade de discursos, práticas e arranjos sócio-culturais que abarcam uma infinidade de realidades, tanto religiosas como não religiosas, mas cuja inspiração leva a uma vivência caleidoscópica (Amaral, 1999). Os contornos deste movimento começam a se delinear ainda no século XIX, remetendo às matrizes que formulam sua "base doutrinária", ou, ao menos, a mais presente, já que não podemos afirmar que haja aqui uma base doutrinária unificada, muito pelo contrário, é um movimento cujo um dos sustentáculos é justamente uma antinomia a uma base doutrinária unificada, ao menos em seu aspecto geral. No entanto, é no século XX que a cultura esotérica começa a ganhar fôlego e visibilidade, em especial, com o movimento de contracultura nos Estados Unidos e Europa, suas proposições espirituais, neste sentido, alinham-se a ideia de uma "sociedade alternativa", de um não alinhamento ao "sistema".

Podemos afirmar, de modo genérico, que a vivência de uma cultura esotérica ganha relevo em momentos distintos ao redor do mundo, de modo que, no Brasil, teremos uma visibilidade maior desta cultura esotérica a partir dos anos 70 e 80 (Andrade, 2002; Magnani, 2000). É relevante destacar que, o momento político pelo qual o Brasil, assim como boa parte da América Latina, passava, em parte explica, o centramento do debate cultural em torno de outras questões, naquele momento histórico, mas por outro lado, há que se chamar a atenção para o fato de que, houve um intenso debate em torno do movimento de contracultura, de forma ampla, o que foi significativo, para a recepção dos discursos e práticas esotéricas no Brasil, uma vez que, o próprio movimento de contracultura encontra-se na base do que chamaremos de movimento Nova Era - NE (Amaral, 2000; Magnani, 2000). 
Interessa-nos, mais ainda, avançar no debate acerca da NE no Brasil, assumindo a postura analítica de que, tal movimento toma aqui um caráter idiossincrático, ao articular, em certa altura, suas práticas e discursos com aqueles presentes na religiosidade popular, tomando assim, um caráter completamente novo (Oliveira, 2011b; 2012). Ainda que isso não tenha sido recorrente no princípio da difusão deste movimento no Brasil, pois como nos aponta Magnani (2006):

Mesmo com a valorização das tradições indígenas, e do contato mais estreito com as religiões ayahuasqueiras como o Santo Daime e a União do Vegetal, o neo-esoterismo no Brasil mantinha uma feição antes universal que local: muito mais frequentes eram as referências aos índios as planícies norte-americanas, a Castañeda, aos incas, ao xamanismo siberiano - isso para não falar na presença do esoterismo europeu, das filosofias orientais, dos cultos de mistério da Antiguidade Clássica, da tradição wicca, do paganismo celta, etc. (Ibidem, p. 171).

Todavia, destacamos que há uma mudança em curso, que se atrela às mudanças mais amplas da sociedade brasileira, que se substancia especialmente por meio do processo de incorporação de elementos das religiões afro-brasileiras neste universo da NE, em especial por meio de suas práticas oraculares (Prandi, 2004), ainda que haja um processo de ressignificação de tais elementos, considerando as próprias disputas simbólicas postas no campo religioso, muitas vezes os orixás estão presentes porém embranquecidos, afirmados como "espíritos de luz", sem seus charutos, e sem a realização de sacrifícios de animais, por outro lado há também a gradativa incorporação dos elementos das NE entre as religiões afro-brasileiras, sendo emblemático o caso da Umbanda Esotérica (Guerriero, 2009). Em outras palavras:

A Nova Era no Brasil ao sincretizar realiza tal processo dentro de uma brasilidade, com o famoso jeitinho, fala-se em preto-velhos, caboclos, Iemanjá, etc, mas quando indagamos aos nossos informantes se estes são os mesmos daqueles encontrados na umbanda 
e no candomblé, eles enfaticamente destacam que não são, só se aparentam na imagem, mas são outros, seres de luz, evoluídos espiritualmente, que estão aqui para fazer caridade. Neste sentido, encontramos a incorporação do espiritismo kardecista, como um elemento fundamental para cimentar as práticas sincréticas, já que ele remete a uma religião de mediação, ao mesmo tempo próxima das práticas dos cultos afro-brasileiros, por ser uma religião de possessão, mas ao mesmo tempo distante simbolicamente ao ser uma religião de brancos e letrados. (Oliveira, 2011a, p. 81)

Não queremos dizer com isso que a fusão dos mais diversos elementos seja algo novo na Nova Era, de fato não é, o que é novo, é a introdução de elementos que aprioristicamente não estavam presentes, e que estão vinculados a profundos processos de estigmatização, e que, portanto, demandam uma reconstrução valorativa em torno do significado de tais signos, atrelando-se as mudanças não apenas religiosas, como também políticas, étnicas e identitárias, a presença dos elementos do candomblé e da umbanda em meio à "nebulosa místico-esotérica" só se faz possível ante às mudanças mais amplas de nossa sociedade, que nos possibilita repensar as hierarquias simbólicas historicamente construídas, em especial no caso dos cultos de possessão.

\section{CONSIDERAÇÕES FINAIS}

Ao longo desse trabalho buscamos realizar uma análise das transformações ocorridas no campo religioso brasileiro, ainda que, obviamente, devida à própria complexidade da questão, que envolve inúmeros agentes sociais ao longo de um largo período de tempo, o escopo desse trabalho é insuficiente para realizar uma análise mais minuciosa. Acreditamos, contudo, que ao trazermos uma revisão desta temática, explorando o ponto de vista de diversos pesquisadores do campo das Ciências Sociais, realizamos uma contribuição significativa para os estudos tanto no campo da Sociologia quanto da Antropologia da Religião no Brasil. 
O que é válido destacar ante a esse amplo balanço realizado é que o campo religioso brasileiro marca-se por intensos fluxos, dinâmicos, porosos, nos quais os credos demarcam um intenso diálogo. Também valeria a pena destacar que formas como o espiritismo e o protestantismo histórico ao adentrarem no Brasil acabam por se voltar para uma dimensão mais terapêutica e emotiva, deixando claro algumas características sui generis valorizadas no universo religioso brasileiro, que se mostram fundamentais para o processo de legitimação de um credo que enverede por terras brasileiras. Por fim, devemos reconhecer que compreender o religião no Brasil é também compreender a própria sociedade brasileira, suas disputas, tensões e contradições, poderíamos mesmo arriscar afirmar que não há como entender o Brasil sem entender o seu universo religioso.

\section{REFERÊNCIAS}

ALMEIDA, Ronaldo. Religião em transição. In: MARTINS, Carlos Benedito; DIAS, Luiz Fernando Duarte. (Org.). Horizontes das Ciências Sociais: Antropologia. São Paulo: ANPOCS, 2010, p. 367405.

AMARAL, Leila. Carnaval da alma: Comunidade, essência e sincretismo na Nova Era. Petrópolis, RJ: Vozes, 2000.

. Sincretismo em Movimento - O Estilo Nova Era de lidar com o sagrado. In: CAROZZI, María Julia (org.). A Nova Era no Mercosul. Petrópolis, RJ: Vozes, 1999.

ANDRADE, Maristela de Oliveira. 500 anos de catolicismos \& sincretismos no Brasil. João Pessoa: Editora Universitária/UFPB, 2002.

AUBRÉE, Marion; LAPLANTINE, François. A Mesa, O Livro e os Espiritos: Gênese, Evolução e Atualidade do Movimento Social Espírita Entre França e Brasil. Maceió: Edufal, 2009.

BASTIDE, Roger. As religiões africanas no Brasil: Contribuição a uma sociologia das interpretações de civilizações, Vol. 2. São Paulo: Pioneira, 1985.

O Sagrado Selvagem e Outros Ensaios. São Paulo: Companhia das Letras, 2006. 
. Spiritism au Brésil, Archives des Sciensces Sociales des Religions. $\mathrm{n}^{\mathrm{o}} 24,1967$.

BERGER, Peter. A Rumor of Angels: Society and the Rediscovery of the Supernatural. City: Anchor Books Edition, 1970.

. O Dossel Sagrado: Elementos para uma Teoria Sociológica da Religião. São Paulo: Paulinas, 1985.

BIRMAN, Patrícia. Cultos de possessão e pentecostalismo no Brasil. Religião \& Sociedade, Rio de Janeiro, nº. 17, 1996.

BITTENCOURT FILHO, José. Matriz Religiosa Brasileira: Religiosidade e Mudança Social. Petrópolis, RJ: Vozes: Petrópolis; Rio de Janeiro: KOINONIA, 2003.

BOAS, Franz. Significado etnológico das doutrinas esotéricas. São Paulo: Revista Cadernos de Campo, 1994.

BOURDIEU, Pierre. A Distinção: Critica Social do Julgamento. São Paulo: Edusp; Porto Alegre, RS: Zouk, 2007.

- A Economia das Trocas Simbólicas. São Paulo: Perspectiva, 2004a.

. Escritos de Educação. Petrópolis, RJ: Vozes, 1998.

. O Poder Simbólico. Rio de Janeiro: Bertrand Brasil, 2005.

. O Senso Prático. Petrópolis, RJ: Vozes, 2009.

- Os Usos Sociais da Ciência: Por Uma Sociologia Clínica do Campo Científico. ão Paulo: Editora UNESP, 2004b.

. Razões Práticas. São Paulo: Papirus, 1996.

BRANDAO, Carlos Rodrigues. A crise das instituições tradicionais produtoras de sentido. In: MOREIRA, Alberto; ZICMAN, Reneé (Org.). Misticismo e novas religiões. Petrópolis: Vozes, 1994, p. 23-41.

. Fronteira da fé: alguns sistemas de sentido, crenças e religiões no Brasil de hoje. Estud. av., Vol.18, nº. 52. p. 261-288, 2004.

BURITY, Joanildo. Fé na revolução. Protestantismo e o discurso revolucionário brasileiro (1961-1964). 1ª . Ed. Rio de Janeiro: Novos Diálogos, 2011.

- Religião, voto e instituições: notas sobre os evangélicos nas eleições de 2002. In: BURITY, Joanildo; MACHADO, Maria das 
Dores Campos. (Org.). Os Votos de Deus: Evangélicos, política e eleições no Brasil. Recife: Massangana, 2006.

CAMARGO, Cândido Procópio. Católicos, Espíritas e Protestantes. Petrópolis: Vozes, 1973. . Kardecismo e Umbanda. São Paulo: Pioneira, 1961.

CAMPOS, Roberta Bivar Carneiro; GUSMÃO, Eduardo H. Celebração da Fé: rituais de exorcismo, esperança e confiança, na IURD. Revista Anthropológicas, Vol. 19, p. 91-122, 2008.

CAVALCANTI, Maria Laura. O mundo invisivel: cosmologia, sistema ritual e noção de pessoa no espiritismo. Rio de Janeiro: Zahar, 1983.

D'ANDREA, A. O self perfeito e a Nova Era: Individualismo e reflexividade em religiosidades pós-tradicionais. São Paulo: Loyola, 2000.

DOUGLAS, Mary. Pureza e Perigo. Porto: Edições 70, 1991.

DURAND, Gilbert. A Imaginação Simbólica. Lisboa: Edições 70, 2001.

DURKHEIM, Émile. As Formas Elementares da Vida Religiosa. São Paulo: Martins Fontes, 2003.

ELIADE, Mircea. O Mito do Eterno Retorno. Lisboa: Edições 70, 2001.

. O Sagrado e o Profano: A Essência das Religiões. São Paulo: Martins Fontes, 2008.

FANON, Franz. Peles Negras, Máscaras Brancas. Salvador: Editora UFBA, 2008.

FAORO, Raimundo. Os Donos do Poder. Rio de Janeiro: Globo, 1984.

FOUCAULT, Michel. A Palavra e as Coisas. São Paulo: Martins Fontes, 1999.

FREYRE, Gilberto. Casa Grande \& Senzala. Rio de Janeiro: Global Editora, 2006. . Novo Mundo nos Trópicos. Rio de Janeiro: Global Editora, 2011.

GIDDENS, Anthony. As Conseqüências da Modernidade. São Paulo: Editora UNESP, 1991.

Vida em uma Sociedade Pós-Tradicional. In: GIDDENS, Anthony; BECK, Ulrich; LASH, Scott. Modernização Reflexiva: Política, Tradição e Estética na Ordem Social Moderna São Paulo: Editora UNESP, 1997. 
. Mundo em Descontrole: O que a Globalização está Fazendo de Nós. Rio de Janeiro: Editora Record, 2010.

GIUMBELLI, Emerson.O ‘baixo espiritismo' e a história dos cultos mediúnicos. Horiz. antropol. Vol.9, nº.19, p.247-281, 2003.

. Fim da Religião: Dilemas da liberdade religiosa no Brasil e na França. São Paulo: Attar/PRONEX, 2002.

GUERRIERO, Silas. Novas configurações das religiões tradicionais: ressignificação e influência do universo Nova Era. Tomo, Vol. 14, p. 35-53, 2009.

. Novos movimentos religiosos: o quadro brasileiro. São Paulo: Paulinas, 2006.

HALL, Stuart. A Identidade Cultural na Pós-Modernidade. Rio de Janeiro: DP\&A, 2006.

HERSKOVITS, Melville J. Antropologia Cultural. São Paulo: Mestre Jou, 1969.

HERVIEU-LÉGER, Danièle. O Peregrino e o Convertido: A Religião em Movimento. Petrópolis, RJ: Vozes, 2008.

HOLANDA, Sergio Buarque de. Raízes do Brasil. São Paulo: Companhia das Letras, 1995.

- Visão do Paraíso: Os Motivos Edênicos no Descobrimento e Colonização do Brasil. São Paulo: Companhia das Letras, 2010.

LATOUR, Bruno. Jamais Fomos Modernos: Ensaio de Antropologia Simétrica. Rio de Janeiro: Editora 34, 1994.

LEWGOY, Bernardo. A transnacionalização do espiritismo kardecista brasileiro: uma discussão inicial. Relig. soc. Vol.28, no.1, p.84-104, 2008.

. Chico Xavier e a cultura brasileira. Rev. Antropol. Vol.44, $\mathrm{n}^{\circ} .1$, p.53-116. 2001.

- Etnografia da leitura num grupo de estudos espírita. Horiz. antropol. Vol.10, $\mathrm{n}^{\mathrm{o}} .22$, p.255-282, 2004a.

. O Grande Mediador, Chico Xavier e a Cultura Brasileira. Bauru, SP: EDUSC/Brasília: CNPQ-PRONEX, 2004b.

MAGGIE, Yvonne. Medo de Feitiço: Relações entre a Magia e o Poder no Brasil. Rio de Janeiro: Arquivo Nacional, 1992. 
. O Medo do Feitiço. Religião e Sociedade, Rio de Janeiro, nº. 13/1, 1986.

MAGNANI, José Guilherme Cantor. O Brasil da Nova Era. Rio de Janeiro: Jorge Zahar Ed., 2000.

. O Circuito Neo-Esotérico. In: TEXEIRA, Faustino; MENEZES, Renata. (Orgs.) As Religiões no Brasil. Petrópolis, RJ: Vozes, 2006.

MELLO, Glaúcia Buratto Rodrigues de. Milenarismos Brasileiros: Novas Gnoses, Ecletismo Religioso e uma Nova Era de Espiritualidade Universal. In: MUSUMECI, Leonarda (Org.). Antes do Fim do Mundo: Milenarismos e Messianismos no Brasil e Argentina. Rio de Janeiro: Editora UFRJ, 2004.

MARIANO, Ricardo. A reação dos evangélicos ao novo Código Civil. Civitas, Vol. 6, p. 77-99, 2006

Neopentecostais: sociologia do novo pentecostalismo no Brasil. $1^{\mathrm{a}}$. ed. São Paulo: Loyola, 1999a.

. O futuro não será protestante. Ciencias Sociales y Religión, Porto Alegre, Vol. 1, nº. 1, p. 89-114, 1999 b.

. Sociologia do crescimento pentecostal no Brasil: um balanço. Perspectiva Teológica, Vol. 43, p.11-36, 2011.

MEMI, Alberto. Retrato do colonizado precedido pelo retrato do colonizador. Rio de Janeiro: Civilização Brasileira, 2007.

MENDONÇA, Antônio G. Discussão Sobre a Viabilidade do Protestantismo Histórico no Brasil. Notas, Vol.1, nº 3, 1994.

MONTERO, Paulo. Religiões e dilemas da sociedade brasileira. In: MICELI, Sergio (Org.). O que ler na ciência social brasileira (19701995). São Paulo: Editora Sumaré, 1999.

MOTTA, Roberto. Reação a Max Weber no Pensamento Brasileiro: O Caso de Gilberto Freyre. Estudos de Sociologia (Recife), Vol. 13, p.185206, 2008.

. Religiões éticas e religiões sacrificiais: seu crescimento simultâneo no Brasil atual. In: MIELE, Neide (Org.). Religiões: múltiplos territórios. João Pessoa: Ed. Universitária-UFPB, 2007.

- Sacrifício, Mesa, Festa e Transe na Religião Afro-Brasileira. Horizonte Antropológico, Porto Alegre, no 3, p. 31-38, 1995. 
.Tempo e Milênio nas Religiões Afro-Brasileiras. In: XXIV Encontro Anual da ANPOCS. Caxambu: Encontro Anual da ANPOCS, 2000.

MOURA, Clovis. Sociologia do Negro Brasileiro. São Paulo: Ática, 1988.

NEVES, Luís Felipe Baeta. O Combate dos Soldados de Cristo na Terra dos Papagaios: Colonialismo e Repressão Cultural. Rio de Janeiro: Forense Universitária, 1978.

NINA RODRIGUES, Raimundo. O animismo fetichista dos negros baianos. Rio de Janeiro: Biblioteca Nacional, 2006.

OLIVEIRA, Amurabi. “A Nova Era com um Jeitinho Brasileiro: O Caso do Vale do Amanhecer”. Debates do NER, v. ano 12, p. 67-96, 2011 a.

. A Nova Era e New Age Popular: Tranformações das Religiões no Brasil. Cadernos de Pesquisa Interdisciplinar em Ciências Humanas, Vol. 11, p. 65-85, 2011 b.

- Corpos e Corporeidade no Universo da Nova Era. Revista Latinoamericana de Estudios sobre Cuerpos, Emociones y Sociedad, v. s/v, p. 52-64, 2012.

OLIVEIRA, Pedro A. Ribeiro de. A teoria do trabalho religioso em Pierre Bourdieu. In: TEXEIRA, Faustino (Org.). Sociologia da Religião: Enfoques Teóricos. Petrópolis. RJ: Vozes, 2007.

ORO, Ari Pedro. "A política da Igreja Universal e seus reflexos nos campos religioso e político brasileiros". Rev. bras. Ci. Soc. Vol.18, nº.53, p.53-69. 2003.

. Reciben lo que veniran a buscar: nação e poder num encontro evangélico internacional, em Buenos Aires. Relig. soc., Vol.30, nº.1, p.32-52. 2010.

ORTIZ, Renato. A Morte Branca do Feiticeiro Negro. São Paulo: Brasiliense, 1999.

. Anotações sobre religião e globalização. Rev. bras. Ci. Soc. Vol.16, n.47, p.59-74. Out 2001.

PARSONS, Talcott. O Sistema das Sociedades Modernas. São Paulo: Pioneira, 1974.

PIERUCCI, Antônio Flávio; MARIANO, Ricardo. Sociologia da religião, uma sociologia da mudança. In: MARTINS, Carlos Benedito; MARTINS, Heloísa Helena T. de Souza. (Org.). Horizontes das 
Ciências Sociais no Brasil. Sociologia. São Paulo: ANPOCS, 2010, p. 279-301

PIRES, Flávia. Quem tem medo de mal-assombro? Etnográfica, Vol. 13, no2, p.291-312, 2009.

PRANDI, Reginaldo. O Brasil com Axé: Candomblé e Umbanda no Mercado Religioso. Estud. av. Vol.18, nº.52, 2004.

RAMOS, Arthur. A Aculturação Negra no Brasil. São Paulo: Nacional, 1942.

. Introdução à Antropologia Brasileira: As Culturas Europeias e os Contatos Raciais e Culturais. Rio de Janeiro: Casa do Estudante do Brasil, 1947.

. Negro Brasileiro. Rio de Janeiro: Graphia Editorial, 2001.

RIBEIRO, Darcy. O Povo Brasileiro. São Paulo: Companhia das Letras, 2006.

SANCHIS, Pierre. Pra não dizer que não falei de sincretismo. Comunicações do ISER, Vol. 13, nº. 45, p. 4-11, 1994.

. Religiões, religião... Alguns problemas do sincretismo no campo religioso brasileiro. In: SANCHIS, P. (Org.). Fiéis e cidadãos: Percursos do sincretismo no Brasil. Rio de Janeiro: EdUERJ, 2001.

SILVA, Magnólia Gibson Cabral. Esoterismo e movimento esotérico no Brasil. Recife. Tese (Doutorado em Sociologia), Universidade Federal de Pernambuco, 2000.

SILVA, Vagner Gonçalves da. Transes em trânsito - continuidades e rupturas entre neopentecostalismo e religiões afro-brasileiras. In: TEXEIRA, Faustino; MENEZES, Renata. (Orgs.). As Religiões no Brasil: continuidades e Rupturas. Petropolis, RJ: Vozes, 2006.

SOUZA, Jessé. A Ética Protestante e a Ideologia do Atraso Brasileiro. Rev. bras. Ci. Soc. Vol.13, no.38, 1998.

SOUZA, Laura de Mello. O diabo e a terra de Santa Cruz: feitiçaria e religiosidade popular no Brasil colonial. $1^{\text {a }}$. Ed. São Paulo: Companhia das Letras, 1986.

STEIL, Carlos Alberto. Homens e mulheres crentes numa sociedade atéia. Cadernos de Liturgia, n², p.34-51,1993. . Pluralismo, Modernidade e Tradição: Transformações do Campo 
Religioso. Ciências Sociais e Religião. Ano 3, n³, p.115-129, 2001.

STOLL, Sandra Jacqueline. Religião, ciência ou auto-ajuda? trajetos do Espiritismo no Brasil. Rev. Antropol. Vol.45, nº.2, p.361-402, 2002.

WEBER, Max. A Ética Protestante e o Espírito do Capitalismo. São Paulo: Companhia das Letras, 2004.

Economia e Sociedade: Fundamentos da Sociologia Compreensiva. Brasília, DF: Editora Universidade de Brasília: São Paulo: Imprensa Oficial de São Paulo, 1999.

______. Ensaios de Sociologia. Rio de Janeiro: LTC, 1983.

WILSON, Bryan. Secularization. In: ELIADE, Mircea. The International Enciclopedia of Religions. Nova York: Macmillan Pub, 1987.

Recebido: 04/07/2013.

Aprovado: 28/10/2013. 